\title{
Obat Tradisional : Antara Khasiat dan Efek Sampingnya
}

\author{
Shofiah Sumayyah, Nada Salsabila \\ Program Sarjana Farmasi, Fakultas Farmasi, Universitas Padjadjaran, Sumedang, 45363 \\ email: shafiyyahmayya@gmail.com
}

\section{Abstrak :}

Lingkungan mempunyai peran penting bagi manusia untuk memenuhi kebutuhan hidupnya. Bangsa Indonesia secara turun temurun dari generasi ke generasi telah mengenal dan juga menggunakan tanaman yang dimanfaatkan sebagai obat tradisional untuk menanggulangi masalah kesehatan. Pada umumnya penggunaan obat tradisional dinilai lebih aman daripada penggunaan obat modern. Hal ini disebabkan karena obat tradisional memiliki efek samping yang relatif lebih sedikit daripada obat modern. Akan tetapi tetap diperlukan ketepatan penggunaan obat tradisional untuk meminimalisir efek sampingnya, yakni : kebenaran obat, ketepatan dosis, ketepatan waktu penggunaan, ketepatan cara penggunaan, tidak disalah gunakan, dan ketepatan pemilihan obat untuk penyakit tertentu.

Keyword : obat tradisional, khasiat, efek samping

\section{Pendahuluan}

Lingkungan mempunyai peran penting bagi manusia untuk memenuhi kebutuhan hidupnya. Contoh kecilnya makan, tempat tinggal, obat-obatan hingga perawatan tubuh dapat manusia peroleh dari lingkungan. Namun, sayangnya belum banyak kekayaan alam di sekitar kita dimanfaatnya dan dikembangkan dengan sebaik-baiknya oleh manusia.

Bangsa Indonesia secara turun temurun dari generasi ke generasi telah mengenal dan juga menggunakan tanaman yang dimanfaatkan sebagai obat untuk menanggulangi masalah kesehatan.

Bangsa Indonesia membuat obat tradisonal dengan memanfaatkan bahan alam yangmana telah terbukti dangan adanya naskah lama pada daun lontar Husodo (Jawa), dokumen Serat Primbon Jampi, dan relief candi Borobudur yang melukiskan orang sedang meracik obat (jamu) yang mana bahan bakunya berasal dari tumbuhan.

Di seluruh penjuru dunia, obat herbal telah dipercaya akan khasiatnya. Menurut WHO, negaranegara latin banyak memanfaatkan obat herbal sebagai pelengkap pengobatan primer. Contohnya di Negara Afrika $80 \%$ masyarakatnya untuk pengobatan primernya menggunakan obat herbal (WHO, 2003).

Banyak faktor-faktor yang dapat mendorong peningkatan penggunaan obat herbal pada negara maju, diantaranya adalah ingin memiliki harapan hidup yang lebih panjang, disamping itu juga tiap tahun obat herbal semakin luas bagi kita untuk mengakses informasinya serta penggunaan obat modern seperti obat kanker tidak jarang mengalami kegagalan adanya efek samping. 
Untuk penyakit kronis dan degeneratif dalam pemeliharaan kesehatannya, pencegahan dan pengobatannya $\mathrm{WHO}$ menyarankan penggunaan obat tradisional termasuk obat-obat herbal. WHO juga ikut mendukung dalam peningkatkan keamanan dan juga khasiat dari obat herbal tersebut. (WHO, 2003).

Pada umumnya penggunaan obat tradisional dinilai lebih aman daripada penggunaan obat modern. Hal ini disebabkan karena obat tradisional memiliki efek samping yang relatif lebih sedikit daripada obat modern.

\section{Ketepatan Penggunaan Obat Tradisional}

Jika digunakan dengan cara yang tepat maka efek samping obat tradisional relatif kecil meliputi

\section{Kebenaran Obat}

Untuk tercapainya efek farmakologi yang diinginkan, maka kebenaran bahan obat menjadi salah satu dari penentunya. Di Indonesia, terdapat berbagai macam tanaman obat dari berbagai spesies yang kadangkala sulit untuk dibedakan.

Setiap spesies dari tanaman obat memiliki khasiat yang berbeda, sebagai contohnya lempuyang. Di pasaran, ada beragam jenis lempuyang yang sulit untuk dibedakan. Lempuyang emprit dan Lempuyang gajah berwarna kuning serta berhasiat untuk menambah nafsu makan. Namun, bentuk lempuyang emprit relatif kecil dibandingkan dengan lempuyang gajah. Sedangkan lempuyang wangi berwarna putih dan berbau harum dan berhasiat sebagai pelangsing (Sastroamidjojo S, 2001).

Baca : Obat Osteoporosis Berpotensi Membuat Tulang Lebih Rapuh Dalam Jangka Panjang Terdapat kasus di Belgia, 70 orang harus menjalani transplantasi ginjal akibat mengkonsumsi pelangsing dari tanaman yang keliru (WHO, 2003). Dapat dibuktikan bahwa fatal apabila kita salah dalam memilih bahan obat karena tia bahan obat memunyai efek terapi yang berbeda.

\section{Ketepatan dosis}

Seperti halnya obat buatan pabrik, tanaman obat juga tak bisa dikonsumsi sembarangan. Tanaman obat juga memunyai dosis dan aturan pakai yang harus dipatuhi seerti halnya resep dokter. Sebagai contohnya buah mahkota dewa dimana perbandingannya dengan air adalah 1 : 3 artinya untuk menkonsumsi 1 buah memerlukan 3 gelas air. Sementara daun mindi akan menimbulkan khasiat jika direbus sebanyak 7 lembar dengan takaran air tertentu (Suarni, 2005).

Banyak masyarakat beranggappan bahwa tanaman obat bisa dikonsumsi secara sembarangan tanpa dosis yang tepat. Tanaman obat tidak dapat begitu saja dikonsumsi secara bebas. Takaran dan dosis tetap harus sesuai dengan ketentuan. Hal ini tidak menutup kemungkinan bahwa tanaman obat memiliki efek samping.

Sebagai salah satu contoh adalah tanaman dringo (Acorus calamus) yang dipercaya dapat mengobati tingkat stress. Karena di dalam tanaman dringo terdapat kandungan senyawa bioaktif asaron. Tanaman dringo dapat menimbulkan efek relaksasi terhadap otot serta memberikan efek sedatif pada sistem saraf pusat apabila dalam dosis rendah. Akan tetapi, apabila digunakan berlebih dalam dosis tinggi akan menimbulkan efek yang sebaliknya yaitu dapat meningkatkan aktivitas mental. Selain itu, asaron dringo juga dapat memicu timbulnya kanker apabila digunakan secara terus menerus dalam waktu yang lama. 


\section{Ketepatan waktu penggunaan}

Selain dosis dan takaran untuk mengonsumsi tanaman obat harus tepat, waktu penggunaan juga harus tepat untuk meminimalisir efek samping yang timbul. Sebagai salah satu contoh adalah kunyit. Kunyit yang dipercaya dapat mengurangi nyeri pada saat haid justru dapat menyebabkan terjadi keguguran apabila dikonsumsi pada awal masa kehamilan. Oleh karenanya, efek dari tanaman obat sangat dipengaruhi oleh ketepatan waktu penggunaan.

\section{Ketepatan cara penggunaan}

Setiap tanaman obat juga tidak bisa dikonsumsi dengan cara yang sembarangan. Tidak semua tanaman obat memiliki efek dan berkhasiat apabila dikonsumsi dengan cara meminum air rebusannya. Sebagai contoh daun kecubung yang digunakan sebagai bronkodilator digunakan dengan cara dihisap. Namun apabila daun kecubung dikonsumsi dengan cara diseduh justru akan menyebabkan mabuk.

\section{Ketepatan menggali informasi}

Di era zaman yang serba canggih ini sangat mudah untuk kita menggali berbagai informasi melalui internet dan juga media sosial. Namun, tidak sedikit informasi-informasi yang ada tidak di dasarkan pada pengetahuan sehingga justru dapat menyesatkan para pembacanya. Sehingga diperlukan kejelian pada para penggunanya untuk mencari informasi yang valid.

\section{Tidak disalah gunakan}

Tanaman obat tradisional sangat mudah ditemukan. Untuk menggunakan obat-obat tersebut tidak memerlukan resep dokter terlebih dahulu. Sehingga tidak sedikit masyarakat yang mengonsumsi obat tradisional dengan tujuan lain. Sebagai contoh penggunaan jamu untuk menggugurkan kandungan atau menghisap kecubung sebagai psikotropika.

\section{Ketepatan pemilihan obat untuk penyakit tertentu}

Dalam satu jenis tanaman obat terkandung lebih dari satu zat aktif yang memiliki khasiat untuk mengobati penyakit tertentu. Perbandingan antara khasiat dengan efek samping yang ditimbulkan haruslah seimbang. Sehingga masyarakat harus pintar dalam memilih obat tradisional dan memikirkan efek samping yang mungkin dapat timbul.

\section{Daftar Pustaka :}

Basch E, Gabardi S, Ulbricht C, 2003, Bitter melon (Momordica cha- rantia): a review of efficacy and safety, Am J Health Syst Pharm., 60(4): 356-9.

BPOM RI, Pedoman Cara Pembuatan Obat Tra disio $\mathrm{n}$ al Ya n g Baik, $\mathrm{h}$ tt p://po m .go.id/p u blic/ h u k um _per un da n ga n /pdf/ SK\%20CPOTB(1).pdf [diakses 25 Maret 2018].

Girini MM, Ahamed RN, Aladakatti RH, 2005, Effect of graded doses of Mo mordica charantia seed extract on rat sperm: scanning electron microscope study, J Ba- sic Clin Physiol Pharmacol., 16(1): 53-66.

Komp as, BPOM Pekanbaru Tarik 9.708 Kotak Obat Tra disional d ari Pere $d$ aran, http://kompas.co.id/kompas-cetak/0305/11/Fokus/ 306422.htm - 42k , edisi 31 Mei 2003 [diakses 25 Maret 2018]. 
Noble RL, 1990, The discovery of the vinca alkaloids-chemotherapeu- tic agents against cancer, Biochem Cell Biol., 68(12):1344-51.

Patterson S, O'Hagan D., 2002, Bio- synthetic studies on the tropane alkaloid hyoscyamine in Datura stra $\mathrm{m}$ onium; $\mathrm{h}$ yoscya mine is stable to in vivo oxidation and is not derived from littorine via a vicinal interchange process., Phy- tochemistry, 61(3): 323-9.

Sastroamidjojo S, 2001, Obat Asli Indonesia, Dian Rakyat, Jakarta, 170.

Suarni, 2005, Tanaman Obat tak Selamanya Aman, http://pikiran- rakyat.com [diakses 25 Maret 2018].

WHO, 2003, Traditional medicine, http://www.who.int/mediacentre/ factsheets/fs134/en/ [diakses 25 Maret 2018]. 